\title{
The sacred foodscapes of Thai Buddhist temples in Sweden
}

\author{
KATARINA PLANK
}

\begin{abstract}
$T^{T}$ hai Buddhist communities are by far the fastest-growing Buddhist establishments in Sweden, and - contrary to other Buddhist congregations that are mainly clustered in the cities - Thai Buddhist temples can be found in sparsely-populated areas and rural parts of Sweden. This article aims to document and analyse the 'foodscape' of diasporic Thai Buddhism in Sweden. In particular the article identifies and discusses five different strategies used by local communities in order to support their temples in urban as well as rural areas: 1) local support, 2) pre-cooking and freezing, 3) pre-organised almsgiving in nearby cities, 4) change of food gifts, 5) change of the nikaya. A temple's location in a rural area can drive forward a reinterpretation and adaptation of the monk's rules, and contribute to a changing composition of food gifts. Food performs several functions. In addition to the religious functions that are associated with almsgiving, food can also serve as a means of generating bonding and bridging civic social capital, and providing economic income to temples.
\end{abstract}

\section{Introduction}

What to eat and with whom to eat are questions that shape everyday religious practices and are at the core of lived religions (Harvey 2013, McGuire 2008). Since religion is one of the main ways by which migrants build networks (Levitt 2007: 107), foodways become a prominent means of maintaining and negotiating that religion. The term 'foodways' here refers to 'a set of beliefs and practices that govern consumption', that is to say, how food is acquired, prepared, displayed and used, as well as how and where it is consumed (Zeller et al. 2014: xviii).

Early on Buddhism became a migratory religion, and thus the role of food in Buddhist traditions has a long tradition of continuity and change. Food norms and practices have been challenged and adjusted whenever Buddhist religious establishments have spread to new places. Not only have culturallyembedded food norms linked to ascetism been negotiated; new institutional developments and establishments have also contributed to the development 
of new food norms. Today, with increased global flows of migration, religious foodways connected with Buddhist traditions encounter new challenges. In Sweden, Thai Buddhist communities are by far the fastest-growing Buddhist establishments, and - contrary to other Buddhist congregations that are mainly clustered in cities - Thai Buddhist temples can be found in sparsley-populated areas and in rural parts of Sweden. This article aims to document and analyse the 'foodscape' of diasporic Thai Buddhism in Sweden; the special landscape of social and economic relations in regard to food that moulds the diasporic space of Thai Buddhism in Sweden.

Following Kim Knott's emphasis that religions need to be studied 'in localities and particular places' (2005:3) this article aims to explore the 'trajectories of adaptation' (Ballard I 994) that religious foodways may undergo, and it does so by focussing on the 'diaspora space' (Brah r 996: i 8 I) of Thai Buddhism in Sweden; that space in the temples and other religious sites where food is prepared, handled and offered.

How do the Thai Buddhist congregrations support their monks? How is the religious giving of food organised in urban and rural areas? Who is being fed by the food that is being prepared and served in diasporic Thai Buddhist contexts? What functions may food have in diasporic Thai Buddhists contexts?

The article further aims to document the foodscape of Thai Buddhism as it is practised in Sweden, and in particular the strategies used by local communities to support their temples. For this analysis the article will make use of the locative, translocative and supralocative categeories (Tweed I997) in order to analyse how food operates at different levels in the 'cosmization'(Vásquez 20 I I) of Thai Buddhism in Sweden.

\section{Methods}

During 20 I 2 and 20I 3 multi-sited fieldwork was carried out, including participant observations, at nine Thai Buddhist temples in Sweden (at Fredrika, Åsele, Brunflo, Bispgården, Sundsvall, Borlänge, Stockholm, Gothenburg and Eslöv) spreading geographically from the north to the south of the country. Some of the observations have been made on the basis of just one or two visits; others on the basis of recurrent observations in the same temple. Observations have been made to cover weekdays, weekends and festival days, over a total time period of approximately one month. The fieldwork included the visual documentation of material manifestations of foodways (photographs) as well as notes, recordings and the tasting and eating of food. Interviews were conducted with food providers, as well as monks, to gain an understanding of how 
the provision of food is organised and how the food is being prepared outside the temples. An additional study of literature was carried out in order to gain information on historical and contemporary food practices in India, China and Thailand. All of these data sources are instrumental in providing information for the present study.

\section{Thai Buddhism in Sweden}

In Europe, Buddhists constitute the third largest religious migrant group after Christians and Muslims - with about one million immigrant Buddhists. In recent decades the establishment of Asian Buddhist congregations has been motivated by different types of migration: refugee, work and marriage migrations. In total, Sweden has probably some 40,000 Asian Buddhists and some 5, ooo converts (Fredriksson 2013: I I 5 ). ${ }^{1}$

Today the largest Buddhist migrant group in the country is the Thai Buddhists, who come primarily because of love relationships - i.e., marriage migration. However many do also come to work in Sweden, especially since Sweden's legislation concerning migrant workers has been liberalised.

Although Buddhists in Sweden still represent a minority of the population - probably around $0.4^{-0.5}$ per cent, Thai Buddhists have in recent years topped the statistics in terms of work migration and family reunification according to data from the Migration Board. ${ }^{2}$ Unlike other Buddhist diasporic groups which are based on family immigration, the demographic profile in the Thai group is strongly gendered: 8 out of ro Thais who come to Sweden are women. This individually-based migration means that they tend to settle with their partners in different areas all over Sweden, and the establishment of new Thai Buddhist temples reflects the features of this particular demographic group. In contrast to other Buddhist groups that are clustered around the major cities of Gothenburg, Stockholm and Malmö (Plank 2009), Thais are therefore one of the few immigrant groups that are distributed over the whole country including both rural and urban areas (Hübinette 2009). In addition to marriage migration, the Thais have in recent years (since 2006) constituted the largest group of labour migrants, the majority of which come for seasonal work in agriculture

1 The estimation is based on Pew-Templeton Global Religious Futures Project 2014.

2 See Migrationsverket (the Migration Board) nd.a and nd.b. 
and forestry. Especially in the northern areas of Sweden, Thais are engaged in berry-picking during the summer and autumn. ${ }^{3}$

Following the migration pattern, Thai Buddhist institutions have in the last couple of years expanded rapidly from north to south in both urban and rural areas. This development is largely initiated from the grassroots level, according to the religious needs of diasporic Thai Buddhists. The creation of new Buddhist temples and congregations, as well as the extension of invitations to religious specialists are therefore largely dependent on this development. The development in Sweden reflects a transnationalization of Thai Buddhism that has been taking place since the late twentieth century and has grown out of several global factors: growing numbers of Thai migrant communities outside the borders of Thailand; missionary activities supported by the Thai sangha and the Thai government; and a growing global interest in Buddhism that has led to the creation of various (transnational) international communities that include travel and exchanges for the purpose of taking part in Buddhist teachings and meditation (Kitiarsa 2010). Wendy Cadge and Sidhorn Sangdhanoo (2005: I 5-I6) have noted two founding patterns for Thai Buddhist temples in the USA: a grassroots demand based on collectively amassing resources, and as the consequence of a schism within an existing temple organisation, leading to dividing the temple into two. Divided Thai communities have also been noted by James Placzek and Ian Baird (2010) in British Columbia, Canada. In Sweden these patterns of establishment (grassroots demand and schisms) are also to be noted; however there are two additional patterns detectable, one exemplified by a vision-driven attempt to establish a temple at Fredrika, and an official representation of Thai Buddhism at Ragunda to complement the only royal pavilion that has been built outside Thailand. These religious sites, where the Thai state religion is maintained and supported, qualify as what Rogers Brubaker (2005: I) defines as diasporic: that is to say, they are characterised by dispersion, having a homeland orientation and being boundary maintaining. As Steven Vertovec (2004: 282) has suggested the terms 'diaspora', 'migration' and 'transnationalism' are related, but not necessarily found together: 'Diasporas

3 During $20 \mathrm{I}_{3}$ Thais comprised the second largest group of partner/spouse migrants (with $\mathrm{r}, 665$ individuals) in comparison with the year 1986 when Thais comprised the twelfth largest group with 200 individuals who came to live with a partner or spouse. From the year 2007, when the Swedish immigration laws were relaxed, Thais have been the largest group receiving work permits. In 2013 more than three times more Thais have come through work permits than living permits. A total of 6,509 work permits were given to Thais in 2013 according to statistics from the Swedish Migration Board: Migrationsverket nd.a, nd.b and nd.c. 
arise from some form of migration, but not all migration involves diasporic consciousness; all transnational communities comprise diasporas, but not all diasporas develop transnationalism'. To what extent Thais in Sweden can be regarded as developing a diasporic consciousness and expressing diasporic identity is not under scrutiny in this article. Rather it is 'the production and reproduction of social and cultural phenomena' (Vertovec I 997: 289) which may be termed Thai Buddhism, and thus the diasporic space of the temples and other religious sites that is being looked at here.

Thai migrants tend to visit the temples in connection with major national festivals (New Year celebrations, Mothers' Day, Songkran, etc.), as well as personal events such as births and the anniversaries of the death of loved ones, and to a lesser extent in order to attend major Buddhist ceremonies. The temples serve as nodes for Thais living in Sweden, and the temples' catchment areas usually extend over several localities, sometimes involving two to three hours of travelling time. Visiting the temples - and inviting monks into private homes - enables Thais in various cities to come together. Meanwhile, the temples are also transnational arenas for Thai Buddhism where the monks' networks extend across national boundaries. The monks commonly travel between temples in the Nordic counties, as well as to temples in Thailand.

\section{The foodscape of diasporic Thai temples in Sweden}

The notion of 'foodscape' has been deveolped using the concept of 'scape' as it is introduced by Arjun Appadurai in his work Modernity at Large: Cultural Dimensions of Globalization ( I 996). He identifies five different 'scapes': financescapes, ideoscapes, technoscapes, mediascapes and ethnoscapes, based on the idea that people live in constantly changing and shifting 'worlds' that are shaped and influenced by these 'scapes'. H. Brembeck and B. Johansson (2010) elaborate on Appadurai's work, adding 'foodscape' to the typology. A foodscape is 'centered around a food environment' (Mackendrick 20I4: I6), and an institutional foodscape includes 'the physical, organizational and sociocultural space in which [one] encounters meals, food and food-related issues' (Mikkelsen 20 I I: 2 I 5). Gisèle Yasmeen (2008) points out the importance and role of food as a medium in which social relationships are shaped. One interesting aspect of the concept of 'foodscape' is not to note what kind of food is eaten, but to understand where it is consumed and the social and economic circumstances surrounding its consumption. Yasmeen thus emphasises 'the spatialization of foodways and the interconnections between people, food and places. [It] is a term used to describe a process of viewing place in which food is used as a lens to bring into focus selected human relations' (Yasmeen 2008: 525 ). 
When food is used as part of a religious world making activity, this needs to be understood in terms of the logic and history inherent in the religious tradition (Anderson 2005: I6I). The role of food in Buddhist traditions rests both on historical continuity and changes that have taken place when the religious representatives and institutions have been established in new cutural milieus.

Thai Buddhism is part of what can be termed 'a Pali imaginaire' (Collins I 998: I); a shared set of texts, doctrines, values, stories and images that are linked to practices and festivals in Theravadan Buddhism with all its local variations

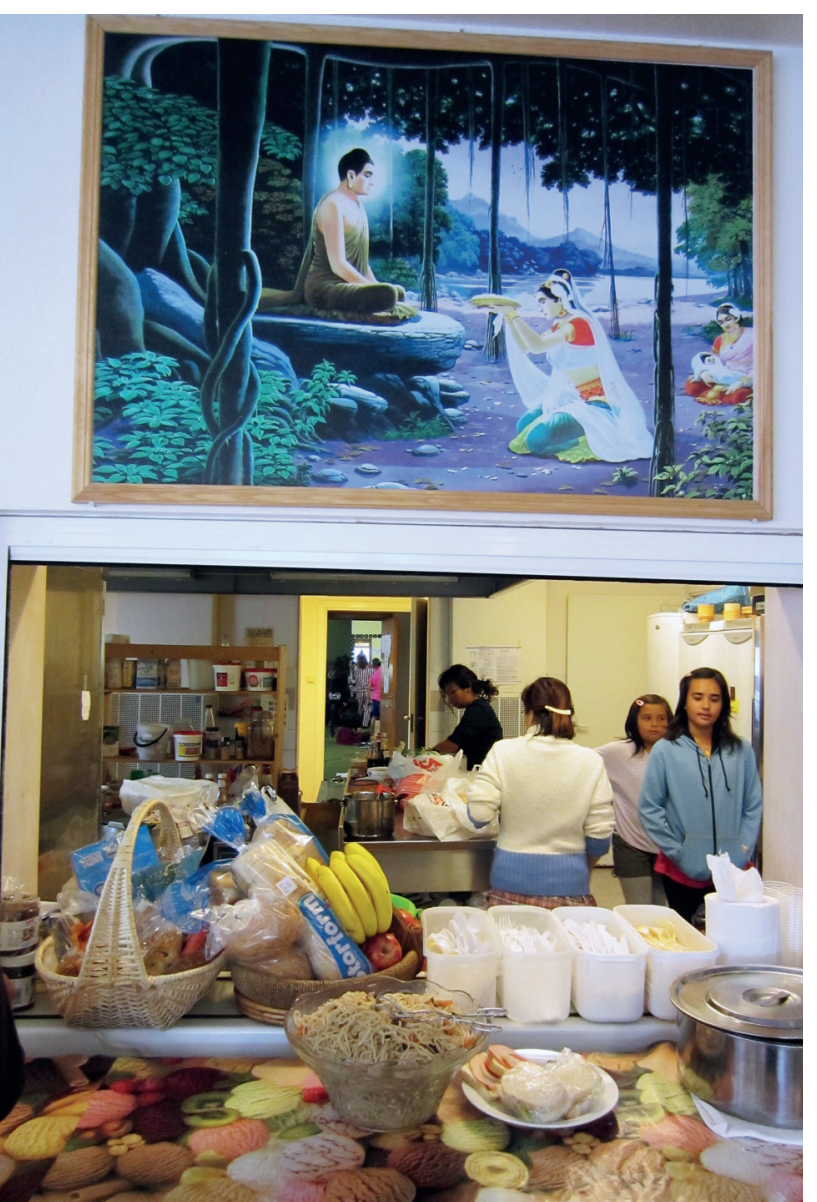

Kitchen view at Wat Dalarnavanaram. The picture on the wall depicts Sujata's meritorious deed of giving milk pudding to the bodhisattva prior to the awakening. Photograph by Katarina Plank. throughout South and Southeast Asia. Theravadan Buddhist temples constitute - both sociologically and geographically - the centre of most villages in Thailand, Cambodia, Laos, Burma and Sri Lanka (Bankston and Hidalgo 2008: 59). Theravadan Buddhist foodways has its roots in an ascetic Indian environment in which the early bbikkbus and bbikkbunis (monks and nuns) lived eremetical lives and wandered around begging for alms. As the wandering life gave way to the establishment of monastic settlements, the Theravadan monks were still not allowed to work or marry and their daily activities remained dependent on interactions with the laity which provided them with food, medicines and clothing. The establishment of monasteries and more permanent living establishments also allowed for the storage of medicines and uncooked staple foods. When Buddhism met with East Asian culture the ideals of asceticism were difficult to accept in the context of the life-affirming Chinese culture, and therefore 
new approaches to food's religious role developed: work was permitted for the ordained, allowing monks and nuns to handle and cook food themselves, and vegetarianism was advocated (Mather i 98 I, Zysk i 99i).

Buddhism can however be regarded as 'a double religion' which has two sets of rules for ordained and lay people respectively (Berglie r 996). The rules that govern monastic life - the vinaya - are thus not a requisite for the laity. The monks' rules permit them to accept cooked food and eat it between sunrise and midday; after this time of the day food is not permitted to be saved. Staple foods, however, such as uncooked rice, may be given to temples and stored.

One of the major dividing lines between the Mahayana and Theravada traditions is that monasteries are organised differently around food and diet, which also affects the ways in which new religious institutions are established when Asian Buddhists migrate outside their home countries. Within Mahayana traditions monks and nuns are allowed to cook their food, while the monks in Theravada traditions depend on the daily ritual giving of food. This ritualised giving of food is organised in different ways in Theravadan countries. In Thailand, the monks' eating habits are governed by the internal rules of the respective monastic Thammayut and Mahanikay orders (nikayas). The Thammayut, having emerged as a result of reforms initiated by King Mongkut in order to modernize the Buddhist tradition, has a close connection to the royal house.

The nikayas are not important in terms of lay devotion and the functions of merit-making (Taylor I 993: 296), however the nikaya affiliation of monks at a temple does have practical consequences in terms of the handling of food. Their disciplinary practices differ, as Mahanikay monks eat two meals a day while the Thammayut monks only eat one meal. Thammayut monks preach in the vernacular languages, while Mahanikay monks recite memorised texts in Pali. An overwhelming majority of temples in Thailand belong to the Mahanikay order (Swearer i 999: 217).

However the centralised sangha in Thailand has been fragmented into smaller communities of faiths and believers' (Whalen-Bridge and Kitiarsa 20I3: 6), a diversity that is also detectable as Thais migrate and re-establish their religious practices and institutions outside their homeland.

Thai Buddhism in Sweden is a bricolage of local and global elements, where the diversity of Thai religion is reflected. The first Thai Buddhist temple in Sweden was established in the year I985, and fifteen years later, in the year 2000 , only two Thai temples were to be found. Fifteen years later again however, in 2015 , there are now some 20 formal congregations (registered organisations) and approximately I 4 temples in which one or more monks live. About 
half of them belong to the Thammayut nikaya and half to the Mahanikay (a reverse proportion compared to Thailand), whilst two temples belong to the Dhammakaya movement.

In the following I will therefore discuss the food transactions taking place in the diasporic space which constitutes Thai Buddhism in Sweden, that is to say, those different Thai religious contexts which involve establishing food connections between lay people (mostly women) and human and non-human beings, some of which are visible and others are not. I will then turn to the food logistics involved in establishing and maintaining a Theravadin Buddhist temple in diaspora, and conclude with some remarks on the functions that food may have in Thai religious contexts in Sweden.

\section{Ritual boundaries and gender}

Ritual boundaries in Thai temples are highly gendered, and made manifest by the cooking and consumption of food. As a social institution, Thai Buddhism has strictly defined gender roles (only men can become fully ordained monks, and they may not have any physical contact with women). Originally the Theravada sangha, or congregation, consisted of both male and female fully ordained monastics (bhikkhu and bhikkbuni). However, women have never been a part of the monastic Thai sangha, for two reasons: the bhikkhuni lineage, with its full ordination of women, died out sometime during the eleventh and twelfth centuries $\mathrm{CE}$ and had not spread to Thailand before then. Additionally, in I 928 , the Thai Supreme Council enacted a law forbidding monks to give the higher ordination to women. Despite this, there is still room for women who want to live a religious life fully; they can either become vernacular 'nuns' referred to as mae chii, or as in a few cases, seek full ordination in another Theravadan country, mainly Sri Lanka, where the reintroduction of full ordination has enabled women to become female monastics. Women are therefore in a subordinate position in the religious field, where they are excluded from the Thai sangha (Lindberg Falk 2008: 96-7).

However, the most important boundary is not between men and women, but between two spheres: lokiya, the secular and worldly sphere, and lokuttara, the other-worldly. Through the centuries this division has also become highly gendered (Lindberg Falk 2008: IOI). Amongst the Buddhist laity, made up of both men and women, practitioners follow the five or eight moral precepts that are associated with the worldly sphere. Their responsibility is to support people associated with the spiritual realm (the other-worldly sphere), who are following ten or more precepts (i.e. novice monks or fully ordained monks). 
This division is reproduced in the Thai temples in Swedish diaspora, and is also reflected in the way in which food is provided.

Observations made at a majority of Thai temples in Sweden reveal a pattern of participation which is divided along lines of gender and ethnicity. Most of the visitors coming to the temples are women between the estimated ages of 25 to 60 years. Younger (childless) women tend to come to the temple in small groups of friends; mothers tend to be accompanied by their children until the children reach the age of ten; women over 45 can sometimes bring their small grandchildren (often children up to three or four years of age).

The temples serve to a large extent as ethnic, cultural and religious centres, however not only ethnic Thais come to the temples. Some of the immigrant women bring with them their Swedish partners/husbands, and other Asian nationals can also be noticed visiting the temples (including lay men and women from Singapore, Taiwan, Sri Lanka, India, Burma). On special occasions (i.e. for instance on birthdays, New Year and festival days), some of the women may want to intensify their religious practice by dressing in white, taking the eight precepts, and staying on for a couple of days as chii phram (temporary nuns, but without having undergone ordination ritual and without shaving their heads as do nuns, mae chii). When they live as temporary nuns in the temples, their religious position is incorporated into the ritual and gendered boundaries that are created the temple, and their special status is also observable in relation to food. The monks usually sit on a raised platform, where their individual positions also reflect seniority: the monk who has been ordained the longest sits closest to the altar and is given food first. The food is then passed on to the more junior monks. Below the platform, a clearly defined and separate space is created for the temporary nuns - often they sit on a mat on the floor. Members of the laity gather on the open floor before the altar, where they sit facing the monks and the temporary nuns. This is also where they partake in a communal meal in which the sacralised leftovers are shared. The boundaries between the otherworldly and worldly spheres are thus clearly separated, not only during rituals but also during the consumption of food. Another spatial boundary, based on gender and ethnicity, can sometimes also be noted when white, male non-Buddhists occupy chairs placed along the walls and remain in a passive role during ceremonies. They tend, however, to join in for the communal meal.

\section{Feeding and sacralised leftovers}

The provision of food is the responsibility of both men and women, although women would normally take responsibility for the cooking and preparation 
of food, both in the family and for monks (Trankell I 995, Van Esterik I998, Wright-St Clair et al. 2004), and this is a responsibility they continue to maintain in Sweden. Thai women occupy a somewhat contradictory position in Thailand and Southeast Asia - they are often considered to be the main provider and bread winner, and as young adults girls are responsible for their parents and younger siblings - a responsibility that continues after marriage, and which is expected also amongst migrant communities. However the Southeast Asian gender system does not constrain women socially or physically to the same extent as it can do in other parts of the world. Women are expected to contribute financially to support their families, and Thai femininity is tied to being an economic provider (Yasmeen 2008: 526-7). Women's economic activities are frequently linked to the food market: over 80 per cent of all small food stalls in Thailand are run by women. When Thai women migrate to Sweden they maintain this financial responsibility, and they regularly send money home to support their family members in Thailand. Thai women's facility for entrepreneurship is also noticeable in Sweden, where many Thai migrants run restaurants and food stalls, or work in the cleaning sector. In urban areas Thai women often run massage and beauty parlours, or food stalls and restaurants. Thai women's employment rate is high, 73 per cent, and they can thus be seen as having strongly integrated into Swedish society (Haandrikman and Webster 20I3).

When Thai Buddhists visit the temples (or invite monks to their homes) the giving of food is the central ritual activity upon which all interactions between the laity and the order are based. The almsgiving ceremony, where the giving of food takes place in the temple, is generally carried out at around I I o'clock in the morning. The act of giving is done in an impersonal, formal and distanced manner (Van Esterik r 998: 87), where eye-contact seldom occurs between donor and recipient. Monks do not ask for food - they are not beggars - but they make themselves available to the laity thus enabling the laity to present them with food gifts. In Sweden the offering of food to the Theravada Buddhist temples may be performed in different ways, depending on how the chief monk wants the almsgiving to be organised. This organisation often reflects the local or regional traditions of the area from which the monks come. The giving of food to the monks is subsequently followed by a communal meal, where the sacralised leftovers are shared.

The ostentious display of food and cooking in Thai Buddhist temples is quickly noted by visitors such as this Swedish male partner who wrote the following in a commemorative publication for one of the temples: 
So, when I came to the temple outside Eslöv I met - a kitchen! Where there are Thais, there are women who prepare and serve food, and it was the first thing I saw before I saw a single monk or Buddha statue. I do not know how different temples can be in Thailand, but I understand that they often function as gathering places for Buddhists as well as temples. In a foreign country like Sweden with few Buddhists the temples may also serve as the main gathering points - as I perceive it. Both religion and food are essential elements in the lives of Thais. This combination also makes farang [white, non-Thai people] curious in different ways. It also makes the Thais curious, those who come without having pondered much on their religion before, and in that way they can get a better foothold for their new life in the new foreign country. (5 th Anniversary Watsanghabaramee, p. 44)

Food can either be prepared by the women in their homes and brought to the temples, or it can be freshly prepared in the kitchen of the temple. The kitchens and dining halls often serve as the main communal area in the temples, a place where people can chat, prepare flower decorations and eat or drink something together. The temples serve as community centres, which is a key feature in Thailand as well as Sweden. The food that is prepared and taken to the temple serves as one of the principal means of reciprocal exchange between the laity and the sangha, and it can also be an aspect of appropriation rituals. Reciprocal exchange and appropriation are the two main ways in which Buddhist rituals work in Southeast Asia today. In reciprocal rituals the concept of karma is at play, and by giving gifts to the sangha (representing the otherworldly sphere) religious merits (thamboon) are received in return. Appropriation rituals can be directed at suprahuman forces, such as the images of the Buddha that are worshipped and whose inherent power can be 'tapped into', or to deities that are pleased with gifts and in return are expected to provide protection (Swearer I 995: 19-22). Both types of ritual can be seen to be at play in relation to food in diasporic religious contexts. Of particular interest is the consumption of food and the sacralised leftovers. Food that is offered in the religious domain to monks, deities, Buddhas, may not be tasted or consumed by the lay people before the offering, and there are noticeable differences in how the sanctified leftovers (what remains of the meal once it is considered to have been consumed by the representatives of the holy) are handled and distributed.

At major festivals, which attract many visitors, the monks may perform a pindipata inside the shrine room, where they pass along a long line of kneeling lay Buddhists who then place a spoonful of rice into each monk's alms bowl. Some of the temples have access to a temple courtyard which instead can be 


Location for food transaction
Reciever of food gift
Presenting a food gift
All food that is given to the
Buddha, to monks or to deities,
should ideally be prepared fresh
and without being eaten of
before it is presented as a gift.
Giving of food is done once a day
at the most.

The gift can be presented to monks in different ways, however it is highly ritualised and characherised by an impersonal, formalised and detached giving, where eye contact is avoided.

\section{Temple/altar}

Other-wordly beings

Laity give a plate of food to a Buddha or monk image.

Human beings

Laity give monks food, and, if present, also to chii prahm.

1. During festivals a pinidpata can be carried out in the temple room (or in the courtyard) when monks walk past the laity who, while kneeling, give rice as a gift in their bowls. Monks then return to their seats, and:

2. Dishes are given separetely to the monks, who acknowledge receipt a) by physical hand contact with the plates (if presented by a male giver) or b) by recieving the plate while placed on a piece of cloth (if presented by a female giver).

\section{Food gifts to the Buddha also include candles, incense and}

Rituals in connection to the giving of food

\section{Consuming of food gifts}

Handling of sacralised leftovers

Monks (and chii prahm) eat the given foods flowers.

When the monks have recieved the food, a recitation follows and a libation ritual, kraut nam, ends the ritual (merits are transffered to dead relatives by pouring water from a small container to another, or on to earth).

When monks (and, if present, chii prahm) have taken foods from the plates, a 'food chain' is created where each individual dish is transported by the laity to a cloth, placed on the floor, around which the laity then gather and eat the leftovers.

Rice left in the monks' bowls, and not consumed by them, may be shared by the laity.

If there are plenty of leftovers after the laity has eaten, this can either a) be divided into separate portions to be brought home, or:

b) be saved in the fridge or deep frezer for the monks to consume at a day when no lay person can be present to give food.

c) the final leftovers can be given to birds or other animals living close to the temple.
Dining hall

Human beings

Laity give food

to monks.

\section{Separate dishes} are placed on a table, and then are given collectively by raising the table symbolically (many individuals cooperate by placing their hands under the table and jointly lifting the table).

4. Every dish is given separetely by (an) individual/s: every plate is lifted and then recieved by a monk with physical contact (see 2 a-b).

Recitations by monks.

Monks eat the given foods.

The plates are transferred from the monks' table to tables where the laity gather afterwards for a communal meal.

Table. Food transactions in Thai Buddhist contexts in Sweden. 


\begin{tabular}{|c|c|c|}
\hline Public space & Private home & Spirit house \\
\hline $\begin{array}{l}\text { Human beings } \\
\text { Laity give food to monks. }\end{array}$ & $\begin{array}{l}\text { Otherwordly beings } \\
\text { When a home has an altar, a food } \\
\text { can be offererd to the Buddha. } \\
\text { Human beings } \\
\text { Monks are invited and given food. }\end{array}$ & $\begin{array}{l}\text { Non-human beings } \\
\text { Outside individual homes, temples } \\
\text { or outside the royal pavilion in } \\
\text { Ragunda, spirit houses have been } \\
\text { erected, where local deites are } \\
\text { presented with food. }\end{array}$ \\
\hline $\begin{array}{l}\text { 5. A pindipata can be carried out } \\
\text { in different public places: a) on a } \\
\text { pre-arranged street, outside a Thai } \\
\text { shop or restaurant, or b) inside a } \\
\text { shop or restaurant where women } \\
\text { have gathered, or c) at a festival to } \\
\text { which the monks have been invited. } \\
\text { Rice and other dishes are given, and } \\
\text { brought back to the temple. }\end{array}$ & $\begin{array}{l}\text { Food is arranged on a plate and } \\
\text { offered to the Buddha. The food may } \\
\text { contain meet. } \\
\text { Food given to monks, is given either } \\
\text { collectivly or individually (se } 3-4 \text { ). }\end{array}$ & $\begin{array}{l}\text { Food is placed on a plate, and may } \\
\text { not contain meat. }\end{array}$ \\
\hline $\begin{array}{l}\text { Recitation by monks, followed } \\
\text { by kraut nam (a libation ritual for } \\
\text { transference of merits). }\end{array}$ & $\begin{array}{l}\text { Recitation by monks, followed } \\
\text { by kraut nam (a libation ritual for } \\
\text { transference of merits). }\end{array}$ & $\begin{array}{l}\text { Food gifts also include candles, } \\
\text { inscence and flowers, and an } \\
\text { invitation to the deities to eat of the } \\
\text { food, with requests for protection. }\end{array}$ \\
\hline \multirow{2}{*}{$\begin{array}{l}\text { Monks return to the temple, where } \\
\text { they eat the food. }\end{array}$} & Monks eat the given foods. & Deites are invited to eat the food. \\
\hline & $\begin{array}{l}\text { The food/leftovers are cleaned } \\
\text { away every day and placed outside } \\
\text { in nature (it may not be consumed } \\
\text { by humans). }\end{array}$ & $\begin{array}{l}\text { The food/leftovers are cleaned } \\
\text { away every day and placed outside } \\
\text { in nature (it may not be consumed } \\
\text { by humans). }\end{array}$ \\
\hline
\end{tabular}




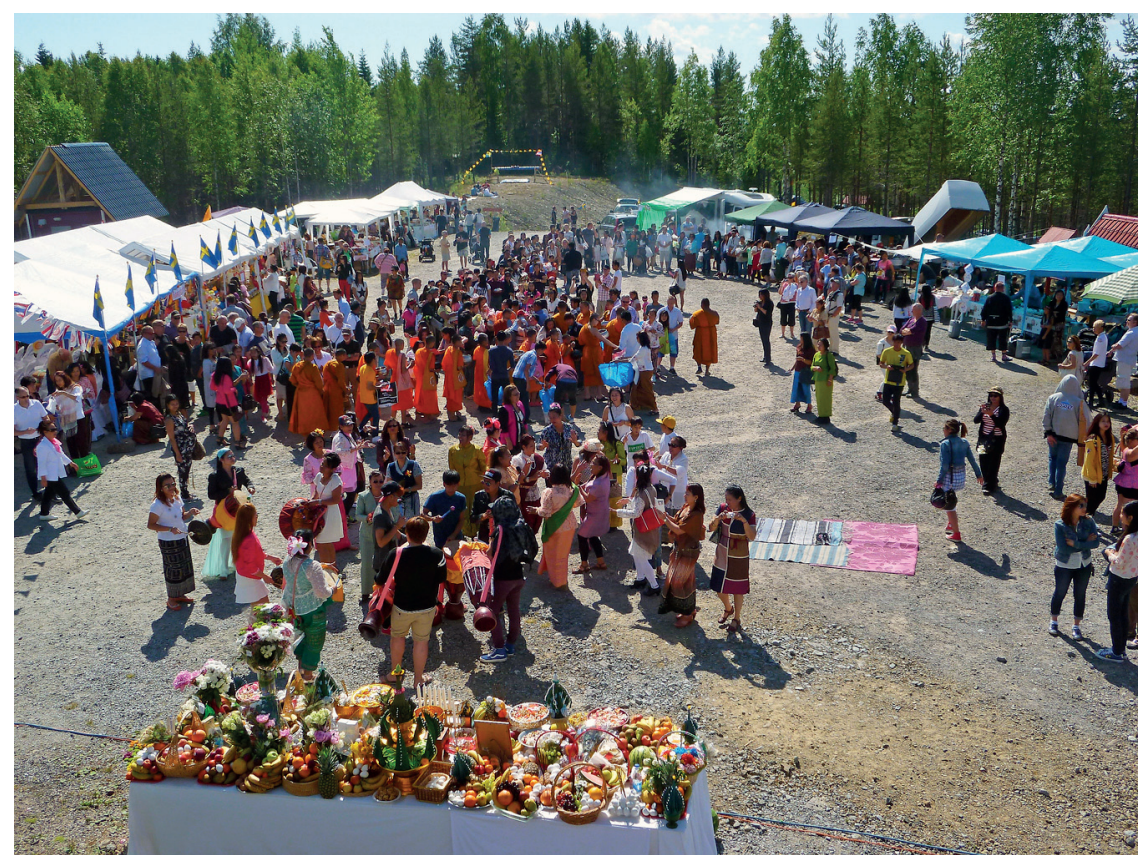

Pindipata at the Temple mountain, Fredrika. Summer festival 2014. Photograph by Marie Ericsson.

used for an outdoor pindipata. The increased presence of Thais in Sweden, even in smaller cities, has made it possible for the monks to carry out public pindipata in towns and cities - this is a noticeable change compared to the early 2000 s when no public pindipata occurred in Swedish cities, but only took place in the temples (Plank 2004). These public pindipatas are usually pre-arranged, and their function will be discussed in the next section of the article.

The giving of food and other meritorious gifts to the sangha are usually public and social events, and their public manifestation is proof that the gift has been given freely. Van Esterik notes that 'It is considered more likely that one has good intentions if the merit-making is public. In fact, if the act of giving is not public it may not be considered an act of merit but rather a personal relationship, a "deal" between the giver and receiver which may be suspect' (Van Esterik 1977: 98, cited in Van Esterik 1998: 93). As noted, in Thai religious contexts in Sweden the giving of gifts usually takes place inside the temple, but the monks can also be invited into private homes.

It varies greatly how often the women come to the temple - some come with their partners during their first three-month visit to Sweden; some make their first visit only after living in Sweden for several years; others come regularly 
every week or month; while still others visit the temple in connection with cyclic celebrations such as birthdays, New Year, or when a child is born or a loved one has died. The frequency of visits to the temples thus seems to depend on the location of the temples, but also on the women's migration histories.

Rice appears frequently as a gift, and especially the sticky rice that is popular in north and northeast Thailand. The Thai word for rice, kbáàw, is also a word used for food in general, thereby demonstrating the importance of rice as a staple in the Thai cuisine. Ing-Britt Trankell's ( I 995) fieldwork was carried out in northen Thailand, where the sharing of rice was seen as a way of creating and maintaining kinship and belonging. The rice was offered to the temple to transfer merit to deceased relatives (ibid. I33-4). Trankell notes that the cooking and giving of food becomes a means by which identity is created and executed (ibid. I03). The responsibility for providing food for family and monks is a practice which is maintained by Thai women in Sweden. (When they bring sticky rice to the temples, they refer, however, to culinary arguments: that the sticky rice goes better with certain dishes, like chicken, for example.) The remit is also extended beyond human beings which enables several different categories of beings to be fed. Thus the feeding may include not only people, such as family members, deceased kin (to whom the transfer of merit is usually done), monks,

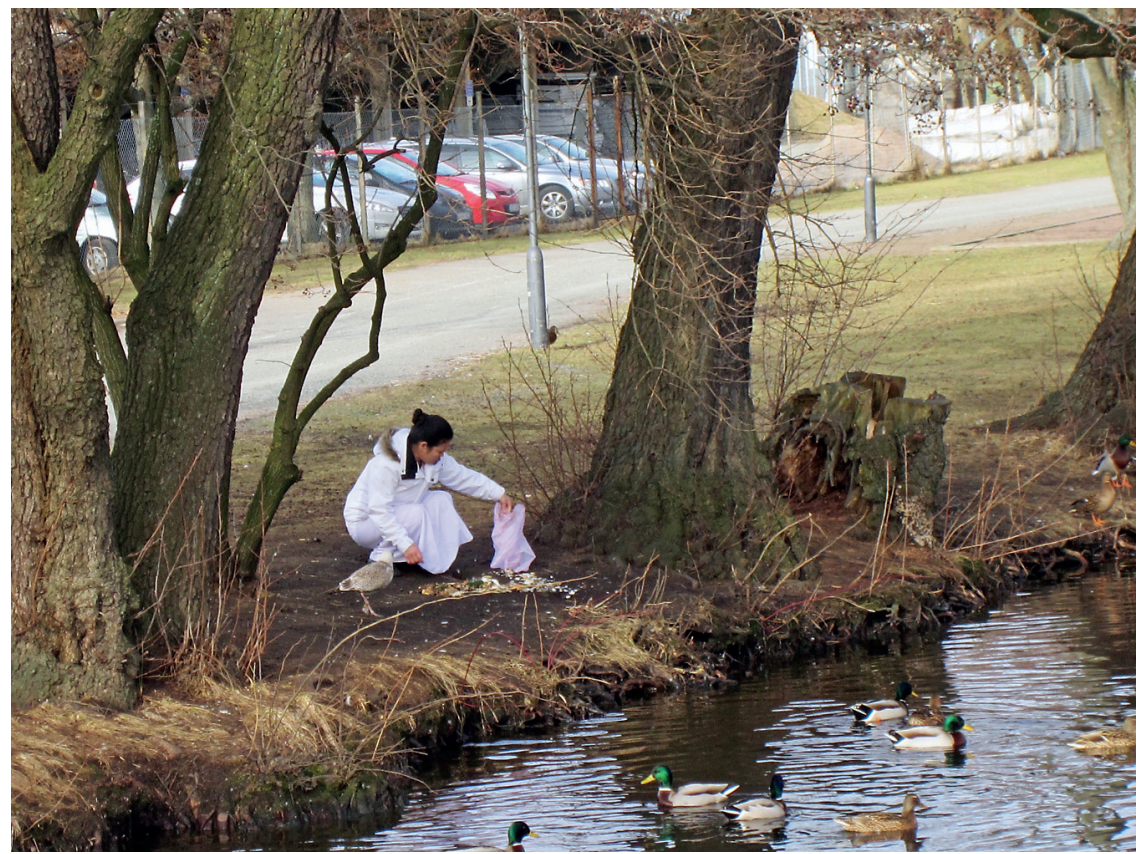

Feeding animals (birds) with leftovers. Photograph by Katarina Plank. 
the Buddha, guardian spirits and deities - but also animals. At several temples, the leftovers from the communal meal may be shared with wild animals, such as birds, foxes, and sometimes even domesticated animals such as cats. Meals and gifts of food are frequently used as a way of controlling other beings such as visitors, or guardian spirits, and are referred to by Trankell (I 995) with the Thai key term liang, meaning 'to domesticate or care for'. Van Esterik has made similar observations with regard to the spirits (I998: 85).

The food given to the Buddha, spirits or monks, should be freshly prepared and must not be consumed by the laity before it is offered. The food given to the spirits should not contain meat - suggesting the upholding of a brabmin tradition where Hindu deities have been incorporated into the Thai religious cosmos (Van Esterik i 998, Trankell r 995).

The remains of food given to the Buddha and to spirits must not be consumed by humans, instead they are (ideally) put out into nature. Only the remains of food given to monks may be ingested by humans. These ritual leftovers - or 'sacralized leftovers' (Trankell r 995: I34) - create a bond that links the laity not only to the monks and the otherworldly sphere, but also to other beings that inhabit the 'samsaric' world.

To sum up: the preparation, sharing and eating of food in the temple can be seen as an expression of belonging to a Buddhist community, and the Thai women living in the diaspora continue to uphold the main responsibility for preparing and distributing food to several different categories of beings: people (family members), the deceased, monks, the Buddha, protector spirits - and even animals.

\section{Food logistics}

The logistics surrounding food is one of the key aspects in the economic maintenance of the temple buildings. A great deal of local support is required to maintain a temple and its resident monks in the context of a diaspora. The daily provision of food is thus not only a central question in terms of how the Theravada tradition will establish itself and survive in such a context; it is also a question of the monks' physical survival.

Five identifiable strategies regarding food logistics can be observed among the Thai Buddhist temples in Sweden: I) local support, 2) pre-cooking and freezing, 3) pre-organised pindipatas in nearby cities, 4) changes in food gifts, and 5 ) change of the nikaya.

Local support. The establishment of Thai Buddhist temples is usually demand-driven and local support is thus the most common way of providing 
the monks with food. This support may be organised through the temple board, and/or carried out by means of individual support. Normally the lay people take it in turns to prepare food for the monks, as well as to receive and assist visitors. They also take care of the general chores around the temple such as laundry and cleaning, or to receive and assist when guests visit the temple. In addition, individual Thai visitors tend to bring fresh food and gifts to the temple and to the monks residing there. The number of visitors varies according to the location of the temple, and whether they come on weekdays or during the weekends.

Temples located in rural areas, for example in Fredrika, Lapland and Bispgården, Jämtland, where only a handful of Thais live, make long-distance travel necessary to support the temple (see Plank et al. forthcoming). These temples have large catchment areas, and travelling to the temple can be a demanding commitment. A woman who wants to visit the temple may need to be up by four o'clock in the morning to prepare food in her home and then (usually) drive a car for two to four hours to get to the temple in time for the almsgiving ceremony at eleven o'clock. This can hardly be combined with a working day, and this means that the women can visit the temples only at weekends. Many Thai women express their desire to have a monk available at close range, and that they would prefer to have a temple housed in a small apartment in their nearest city than having to go to a larger, remote temple which is difficult to travel to.

If the temple is located outside a town, or in an area where few Thais live, there is therefore a need for alternative ways of ensuring that the monks get the food they need. This includes other strategies such as:

Pre-cooking and freezing. Leftovers from festival meals can be frozen and saved for the monks (the food has thus already been given to them). Precooking and freezing is another alternative that I have noted being used in rurally-situated temples.

Pre-organised pindipatas in nearby cities. If a temple is situated outside a town, and there is limited public transport to the temple, the temple board may pre-organise pindipatas in nearby cities during the weekends. The gifts of food are then brought back to the temple, stored or freezed, and used at times when no lay person is able to visit the temple in order to prepare food. The freezing of food has also contributed to a fifth observable strategy, described below.

Changes in food gifts. The food items given during pre-organised pindipatas or as offerings to rurally-situated temples tend to change. Rural challenges not only mean a forced reinterpretation and adaptation of tradition on the part of the monks (cooked food should not be saved according to monastic rules) - even the composition of the gift has changed. The monks are still given 
freshly-cooked Thai food, but among the gifts one can also find processed food items, such as single portions of frozen 'Sausage Stroganoff' from Dafgards, and 'Falafel Marrakesh' from Findus.

Change of nikaya. The Thai sangha consists of two nikayas, or orders of monks, the stricter Thammayut nikaya and the more liberal Mahanikaya. In the stricter and reformed Thammayut nikaya monks encourage the lay women to come to the temple with gifts of food every day, so that they do not compromise the vinaya rules (which the storing and reheating of food can imply). This has however put too much strain on the community at Bispgården. I was told by a woman visiting the temple, that they needed to invite monks from the Mahanikaya instead to stay at the temple, in order for the food logistics to work. The monks belonging to the Mahanikaya order have been more willing to compromise and be permissive in their interpretation of the monks' rules. The women can therefore pre-cook and freeze foods.

The replacement of home-cooked meals with frozen food reveals changing food habits which are motivated mainly by the conditions which pertain in the depopulated rural areas of Sweden. These changes, along with the inclination towards the more liberal Mahanikaya that I have observed, involves making a compromise in regard to vinaya rules that enables the monks to continue living and supporting the local community. This can be seen as a deviation from food and eating patterns usually associated with migration. When people migrate to new countries they change their eating habits slowly, but some groups have proved to be more resistant to change than others. Ethnic groups whose kitchens are becoming popular even among the majority population have less reason to change their eating habits. Where the Thai kitchen is growing more popular among the majority, there is less reason to change food habits. If the migrant group is additionally reinforced with renewed immigration, and if they manage to maintain large and dynamic ethnic enclaves, this also reduces the inclination for change in relation to diet. E. N. Anderson (2005) has noted that there seems to be a universal pattern of eating in a migration context: the first foods that are adopted and exchanged from the new culture are sweets and snacks, followed by drinks. Breakfast habits are then adjusted accordingly to the new cultural environment, and subsequently the lunch diet changes. Dinner, and food for festivals or ceremonies, tend to be preserved the longest (ibid. 203-4). In the diasporic space of Thai Buddhism in Sweden, similar patterns can be noted: the sweets, beverages, and breakfasts that are served are usually based on commonly available domestic Swedish products that can be bought in supermarkets. Lunches, however, often contain ingredients and raw food imported from Thailand by ethnic stores specialising in food imports, and 
lunches usually consist of various regional and traditional cooked dishes from Thailand. However, the composition of food gifts can be affected when a temple is located in remote areas where food cannot be provided every day, and other adjustments in regard to interpretation of monks' rules may be needed to maintain a temple located in rural areas.

\section{Food and civic social capital}

The earlier quote, in which a Swedish male visitor reflects on the temple as a social arena where contacts are made between recent migrants and those migrants already living in the diaspora, shows how important transnational religious networks can be to both maintain and transmit ethnic and transnational identities. It also suggests how food relates to everyday and civic life, both in the old homeland and the new one. Food is thus instrumental in the creation of what A. Stepick and others (2009) term 'civic social capital'. Civic social capital is a concept which is used to describe how individuals create social ties outside the immediate network of family and friends, and specifically on how religious organizations can be of use to establish social relationships with the surrounding civil society. The communal meals in the temple can be understood to be creating a unifying bond between Thai migrants, that is they are a 'bonding' form of civil social capital that unites people with similar backgrounds. Food, however, can also contribute to creating a form of 'bridging' civil social capital by tying together people with different backgrounds. Bridging civil social capital is often created through a variety of services and volunteer activities. The exchange of food helps people from different backgrounds to connect at temple festivals and local markets. In this way food exchange serves as a bridge for social capital by linking people together. This happens when the temple compounds are used as festival arenas and food stalls where lay women from different regions or cities in Sweden can cook and sell Thai food to the festival participants (often also attracting non-Buddhists), and where the income is donated to the temple. Similar instances of bridging social capital can also be observed at various food markets, such as Åsele market and the Thai Festival in Sundsvall, in which the Buddharama temple in Fredrika participated in both 2012 and 2013.

Overall, food performs several functions in diasporic Thai Buddhism in Sweden. In addition to the religious functions that are associated with almsgiving (that is, a meritorious gift that augments an individual's karma) food can also serve as a means of generating bonding and bridging civic social capital. Temples in rural areas are faced with special challenges when the laity, due to 
long distances cannot come to the temple every day so that the continous giving of dana is difficult to secure. Food sold at festivals can thus have an important economic function for the congregations, as the selling of food at various festivals can help pay the rent, heating bills or clear debts for several months to come.

\section{Cosmization of life}

The food that is cooked, donated and consumed in Thai Buddhist religious contexts in Sweden is also a medium through which religion is manifested; a medium that operates on several different levels. Thomas Tweed (1997) has noted that religion in a migration context can operate on locative, translocative and supralocative levels. Locative religion is where the sacred manifests itself in the local landscape and the material environment. The establishment of Thai temples in villas, or the building of a small spirit house outside a private house, are examples of how religion operates in a locative level. Religion can also be translocative as it links the diaspora to their homeland in different ways through time and space - often through symbolic links. In the Thai temples this is done in particular by various visual decorations: portraits of King Bhumibol Adulyadej and Queen Sirkrit often hang in the temple room near the altar; curtains or other cloth items that are used as decoration are dyed in the royal blue and yellow colours; popular Jataka stories and the history of Thai Buddhism can be represented in images hanging on walls; as well as portraits of prominent Thai monks that hang on display in the shrine room. However, these visual representations are not the only aids to creating a translocative dimension - so does also taste and smell. Food that is cooked, served and consumed in temples plays an important role in creating a translocal religion: the food contains specially imported vegetables and spices grown in Thailand. The food is also based on different kinds of rice, where the sticky, steamed rice is central, and supplemented by various regional dishes from the places the women come from (especially from Isaan in north-eastern Thailand), thereby linking the eating and tasting of food to the home country.

In addition to this 'horizontal' linking, from local places in the Swedish diaspora to the Thai homeland, there is also the possibility of a vertical and cosmic link to a suprahuman dimension, which also finds expression in the giving of food. Food is not only given to humans representing the otherworldly sphere, but also to other beings in the 'samsaric' world: the Buddha, place-bound spirits or deities, and merits are transferred to dead relatives. Food given to the monks changes in character from having belonged to the secular and worldly (lokiya) 
sphere to being received into the otherworldly (lokuttara) sphere. When the leftovers are consumed by the laity, they thereby also consume an otherworldly materiality. One could say, to adopt Manuel Vásquez' expression, that the food creates a 'cosmizing' dimension, since it allows the sacred and holy to penetrate time and space: 'Cosmization - the irruption of the absolute time and space of the sacred into history and geography - represents one of the most distinctive and significant contributions of religion to the diasporic experience' (Vásquez 2OI I: I 3 I-2). Samsaric existence is cosmized and made present not only in the feeding of different beings, but also in the bodies of the lay men and women as the food is ingested.

The cosmizing dimension of food is intimately connected with the social relationships that are created and maintained by the feeding, and with the 'foodscape' that can be found in diasporic Thai temples in Sweden. By the giving of social and religious gifts obligations are created; food transactions can also be a way to control others - especially protective spirits.

In addition to the religious purpose of almsgiving, food and food exchange serves the Buddhist congregation in several other ways. The feeding that takes place in the foodscape of the diasporic space of Thai Buddhism in Sweden does not only include human beings - even the Buddha and place-bound spirits and deities are given food, and the sacralised leftovers from the monks' meals are shared by the lay Buddhists in a commmunal meal. Even animals can come to partake of these sacralised leftovers. Through food the samsaric existence is reproduced, and the lives of Thai migrants are cosmized. Food and feeding link the various samsaric existences together, and food can also be used to control spirits, and to ensure the welfare of dead relatives.

The communal eating in the temple also helps to strengthen the bonds amongst Thais living in Sweden, and food also becomes a way of maintaining religious, national, regional and ethnic identities. In the diasporic space of Thai Buddhism in Sweden food can also be used in the marketing of the temples and as a source of income. Food may thus contribute to the creation of both bonding and bridging civic social capital.

A temple's location in a rural area can also drive forward a reinterpretation and adaptation of the monks' rules, and contribute to a changing composition of food gifts. The analysis of the foodscape also shows how intrinsic Buddhist structures are maintained by the practice of giving food. The globalisation of Thai Buddhism shows that local Asian traditions are transmitted into new 
cultural contexts where food practices are negotiated, and how the handling of food can be understood as social and gendered patterns related to ethnicity.

Katarina Plank works as a historian of religion and a postdoctoral researcher at the Department of Literature, History of Ideas, and Religion, University of Gothenburg. She was awarded her doctorate by Lund University in 2011 for a thesis on Buddhist meditation and mindfulness. Her main research interest concerns the continuation and change of religious traditions when transposed to a new context, and in particular how Buddhist traditions are received and incorporated into a Swedish context, as well as how individuals perceive and make use of these traditions. Her research emphasises fieldwork designed to acquire new data on Buddhist traditions in Sweden.

\section{References}

Anderson, E. N., 2005. Everyone Eats: Understanding Food and Culture (New York University Press)

Appadurai, Arjun 1996. Modernity at Large: Cultural Dimensions of Globalizations (Minneapolis, University of Minnesota Press)

Ballard, Roger, 1994. 'Introduction' in Desh Pradesh: The South Asian Presence in Britain (London, C. Hurst), pp. I-34

Bankston, Carl, and Danielle Hildago, 2008. 'Temple and society in the New World: Theravada Buddhism and social order in North America' in North American Buddhists in Social Context, ed. Paul Numrich (Leiden, Brill), pp. 5 I-85

Berglie, Per-Arne, I 996. 'Dessa underbara droppar jag druckit... Synen på berusningsmedel inom hinduism och buddhism' in Rus $\mathcal{E}^{2}$ rit. Om droger och religioner, ed. Håkan Rydving (Örebro, Bokförlaget Libris), pp. 88-105

Brah, Avtar, I 996. Cartographies of Diaspora (London, Routledge)

Brembeck, H., and B. Johansson, 2or o. 'Foodscapes and children's bodies', Culture Unbound, 2, pp. 797-8 I 8

Brubaker, Rogers, 2005. 'The "diaspora” diaspora', Ethnical and Racial Studies, 28( I), pp. I-I 9

Cadge, Wendy, and Sidhorn Sangdhanoo, 2005. 'Thai Buddhism in America: an historical and contemporary overview', Contemporary Buddhism, 6(I), pp. 7-35

Collins, Steven, 1998. Nirvana and Other Buddhist Felicities (Cambridge University Press)

Dallam, Marie, 20 I 4. 'Introduction: religion, food and eating' in Religion, Food, and Eating in North America, Benjamin Zeller et al. (New York, Columbia University Press)

Fredriksson, Trudy, 2013. Uppvaknandets vägar. Frän buddhistisk historia till nutidens utöuning och gemenskap, SST:s skriftserie, 2 (Bromma, Nämnden för Statligt Stöd till Trossamfund)

Haandrikman, Karen, and Natasha Webster, 201 3. 'Thai women in Sweden: passive victims or active participants' [poster] (Stockholm University)

Harvey, Peter, 20 1 3. Food, Sex E Strangers: Understanding Religion as Everyday Life (Warwick, Acumen) 
Hübinette, Tobias, 2009. Demografisk översikt över de 32 största invandrargrupperna i de 24 största kommunerna (Tumba, Mångkulturellt centrum; Stockholm, Konstnärsnämden)

Kitiarsa, Pattana, 20 Io. 'Missionary intent and monastic networks: Thai Buddhism as a transnational religion', Journal of Social Issues in Southeast Asia, 25(I), pp. 109-32

Knott, Kim, 2005. The Location of Religion (Cambridge, Acumen)

Levitt, Peggy, 2007. 'Redefining the boundaries of belonging: the transnationalization of religious life' in Everyday Religion: Observing Modern Religious Life, ed. Nancy Ammerman (Oxford University Press)

Lindberg Falk, Monica, 2008. 'Gender and religious legitimacy in Thailand' in Gender Politics in Asia: Women Manoeuvering within Dominant Gender Orders, ed. Wil Burghoorn et al. (Copenhagen, NIAS Press)

Mackendrick, Norah, 20 I 4. 'Foodscape', Contexts, I3(3), pp. I6-г 8

Mather, Richard, I98 I. 'The Bonze's begging bowl: eating practices in Buddhist monasteries of medieval India and China', Journal of American Oriental Society, IOI (4), pp. 4I 7-24

McGuire, Meredith, 2008. Lived Religion: Faith and Practice in Everyday Life (Oxford University Press)

Migrationsverket, nd.a. 'Beviljade uppehållstillstånd av arbetsmarknadsskäl efter medborgarskap 2000-201 2', <http://www.migrationsverket.se/ Om-Migrationsverket/Statistik/Oversikter-och-statistik-fran-tidigare-ar.html> (accessed I.3.2014)

— nd.b. Beviljade uppehållstillstånd och registrerade uppehållsrätter, första och andra instans (beslut av Migrationsverket och Migrationsdomstolarna). Förstagångstillstånd 2013, <http://www.migrationsverket.se/Om-Migrationsverket/Statistik/ Oversikter-och-statistik-fran-tidigare-ar.html> (accessed I.3.2014)

— nd.c. Beviljade uppehållstillstånd till nära anböriga (familjeanknytning) efter medborgarskap 1986-2012, <http://www.migrationsverket.se/Om-Migrationsverket/ Statistik/Oversikter-och-statistik-fran-tidigare-ar.html> (accessed I.3.20I4)

Mikkelsen, Bent Egberg, 20 I r. 'Images of foodscpaes', Perspectives in Public Health, I 3 I (5), pp. 209-I6

Pew-Templeton Global Religious Futures Project, 20 I 4. <http://www.globalreligiousfutures.org/explorer\#/?subtopic=23 \&chartType=bar\&year=20 1 $\& d$ ata_type $=$ number\&religious_affiliation $=$ all\&regions $=$ Europe $\&$ destination $=$ to $>$ (accessed I.3.2014)

Placzek, James, and Ian Baird, 20 го. 'Thai and Lao Buddhism' in Asian Religions in British Columbia, ed. Larry DeVries, Don Bake, and Dan Overmyer (Vancouver, University of British Columbia Press)

Plank, Katarina, 2004. 'Buddhism i Sverige' in Det mångreligiösa Sverige. Ett landskap i förändring, ed. Daniel Andersson and Åke Sander (Lund, Studentlitteratur)

—— 2009. 'Buddhister och buddhism' in Det mångreligiösä Sverige. Ett landskap i förändring, ed. Daniel Andersson and Åke Sander (Lund, Studentlitteratur) 
Plank, Katarina, Elisabeth Raddock, and Peter Selander, forthcoming. 'The Temple Mount of Fredrika', Contemporary Buddhism.

Stepick, A. et al., 2009. Churches and Charity in the Immigrant City: Religion, Immigration and Civic Engagement in Miami (New Brunswick, NJ, Rutgers University Press)

Swearer, Donald, I 995. The Buddhist World of Southeast Asia (Albany, State University of New York Press)

- r 999. 'Centre and periphery: Buddhism and politics in modern Thailand' in Buddhism and Politics in Twentieth-Century Asia, ed. Ian Harris (London, Continuum), pp. I 94-228

Taylor, J. L., I 993. Forest Monks and the Nation-State (Singapore, Institute of South Asian Studies)

Trankell, Ing-Britt, I 995. Cooking, Care and Domestication: A Culinary Ethnography of the Tai Yong, Northern Thailand (Uppsala University)

Tweed, Thomas, 1997. Our Lady of the Exile: Diaspora Religion at a Cuban Shrine in Miami (Oxford University Press)

Van Esterik, Penny, I 977. Cultural Interpretation of Canonical Paradox: Lay Meditation in a Central Thai Village, PhD dissertation, University of Illinois, Champaign

— 1998 . 'Feeding their faith: recipe knowledge among Thai Buddhist women' in Food and Gender: Identity and Power, ed. Carole Counihan and Steven Kaplan (Abingdon, Harwood Academic Publishers)

Vásquez, Manuel, 20 I I. More than Belief: A Materialist Theory of Religion (Oxford University Press)

Vertovec, Steven, I 997. 'Three meanings of "Diaspora" exemplified among South Asian religions', Diaspora: A Journal of Transnational Studies, 6(3), pp. 277-99

2004. 'Religion and diaspora' in New Approaches to the Study of Religion, ed. Peter Antes, Armin Geertz, and Randi Warne (Berlin, Walter de Gruyter)

Whalen-Bridge, John, and Pattana Kitiarsa (eds), 2or 3. Buddhism, Modernity, and the State in Asia: Forms of Engagement (London, Palgrave)

Wright-St Clair, Valerie, et al., 2004. 'Offerings: food traditions of older Thai women at Songkran', Journal of Occupational Science, I I (3), pp. I I 5-24

Yasmeen, Gisèle, 2008. "Plastic-bag housewives" and postmodern restaurants? Public and private in Bangkok's foodscape' in Food and Culture: A Reader, ed. Carole Counihan amd Penny van Esterik (Abingdon, Routledge)

Zeller, Benjamin et al., 20 I 4. Religion, Food, and Eating in North America (New York, Columbia University Press)

Zysk, Kenneth, I 99 I. Ascetism and Healing in Ancient India (Oxford University Press) 